\title{
Justyna Światowiec-Szczepańska
}

Uniwersytet Ekonomiczny w Poznaniu

e-mail: justyna.swiatowiec-szczepanska@ue.poznan.pl

\section{LOGIKA SZANS I PROSTYCH REGUL \\ W WARUNKACH PRZECIĄŻENIA \\ INFORMACYJNEGO MENEDŻERÓW}

LOGIC OF OPPORTUNITIES AND SIMPLE RULES

IN THE CONDITIONS OF INFORMATIONAL

OVERLOADING OF MANAGERS

DOI: $10.15611 /$ pn.2018.538.34

JEL Classification: D01, D81, D9

Streszczenie: Artykuł ma charakter koncepcyjny. Podjętym problemem jest podejmowanie efektywnych menedżerskich decyzji strategicznych w specyficznych warunkach przeciążenia informacyjnego w dynamicznym otoczeniu. Celem artykułu jest wskazanie luki badawczej z tego zakresu. Podstawowym założeniem rozważań jest ograniczona racjonalność menedżerów rozumiana jako ograniczone zdolności człowieka w zakresie dostępu i przetwarzania informacji. W pierwszej części artykułu przedstawiono istotę przeciążenia informacyjnego. W kolejnej opisano mechanizmy adaptacyjne i heurystyczne podejmowanie decyzji. Wskazano, że w określonych sytuacjach mogą one odgrywać rolę strategii w organizacjach. W rozważaniach wskazano znaczenie podejścia „racjonalno-heurystycznego”, zwanego logiką prostych reguł, będącego alternatywą wobec podejść zasobowego i pozycyjnego w zarządzaniu strategicznym. W wyniku przeprowadzonej analizy zidentyfikowano luki badawcze zarówno w zakresie badań deskryptywnych, jak i preskryptywnych.

Słowa kluczowe: logika prostych reguł, przeciążenie informacyjne, podejmowanie decyzji strategicznych.

Summary: The article is of conceptual nature. The undertaken problem is effective managerial strategic decisions in specific conditions of information overload in a dynamic environment. The aim of the article is to indicate the scope of the research gap in this field. The basic assumption of considerations is the bounded rationality of managers understood as limited human capabilities in the field of access and information processing. The first part of the article presents the essence of information overload. The next describes the mechanisms of adaptation and heuristic decision making. It was pointed out that in specific situations they may play the role of strategy in organizations. The considerations indicate the importance of the „rational-heuristic” approach, called the logic of simple rules, being an alternative to resource and positional approaches in strategic management. As a result of the analysis, research gaps were identified both in the scope of descriptive and prescriptive research.

Keywords: logic of simple rules, information overload, making strategic decisions. 


\section{Wstęp}

U podstaw sukcesu każdej firmy leżą wybory strategiczne i związane z nimi podejmowanie decyzji strategicznych. Kluczowym determinantem efektywności decyzji strategicznych są posiadane informacje. Z tego względu dla każdego przedsiębiorstwa informacja jest zasobem krytycznym, uznanym w ekonomii w XX wieku za jeden z czynników produkcji obok klasycznych, takich jak kapitał, ziemia i praca [Arnott i in. 1994]. W literaturze zarządzania poświęcono wiele uwagi badaniom dotyczącym radzenia sobie menedżerów z niedoborem informacji i związaną z tym niepewnością [Dean, Sharfman 1993; Mintzberg i in. 1976]. Sama informacja nie gwarantuje jednak sukcesu. Istotnym problemem staje się bowiem proces jej przetworzenia i zdolności poznawcze decydentów. Problematyczny z punktu widzenia menedżerów jest zatem nie tylko niedobór informacji, lecz także jej nadmiar. Wraz $\mathrm{z}$ rewolucją informacyjną i ogromną podażą informacji z jednej strony oraz z presją czasu wynikającą z potrzeby elastyczności przedsiębiorstw w dynamicznym otoczeniu z drugiej strony coraz większym problemem menedżerskim staje się odczuwane przeciążenie informacyjne [Edmunds, Morris 2000]. Wiąże się ono z ilością docierających informacji przekraczającą ludzkie zdolności do przetwarzania informacji oraz z dopływem informacji sprzecznych, wywołujących dysonans poznawczy. Istotnym problemem staje się zatem radzenie sobie ze stanem przeciążenia informacyjnego na poziomie menedżerskim i organizacyjnym oraz efektywność strategicznych decyzji podejmowanych w takich warunkach. Można przypuszczać, że od tych umiejętności zależy sukces współczesnych przedsiębiorstw funkcjonujących w dynamicznym otoczeniu wymagającym elastyczności.

Problemem podjętym w artykule jest podejmowanie efektywnych menedżerskich decyzji strategicznych w specyficznych warunkach przeciążenia informacyjnego w dynamicznym otoczeniu, natomiast bezpośrednim celem artykułu jest wskazanie luki badawczej z tego zakresu. Podstawowym założeniem rozważań jest ograniczona racjonalność menedżerów rozumiana jako ograniczone zdolności człowieka w zakresie dostępu i przetwarzania informacji.

\section{Przeciążenie informacyjne i syndrom ,zmęczenia informacyjnego"}

W literaturze psychologicznej dość powszechnym założeniem jest stwierdzenie, że wraz ze wzrostem napływającej informacji poziom przetwarzania informacji przez człowieka wzrasta do pewnego zakresu, a następnie spada [Klausegger i in. 2007]. Zjawisko to wiąże się ze specyficznym stanem zwanym przeciążeniem informacyjnym (information overload). Nie ma jednej ogólnie przyjętej definicji przeciążenia informacji. W odniesieniu do jednostki termin ten zwykle oznacza sytuację, w której efektywność danej osoby w korzystaniu z informacji w pracy jest ograniczona ze względu na nadmiar dostępnych i potencjalnie użytecznych informacji [Baw- 
den i in. 1999]. Przeciążenie informacyjne zatem to ilość informacji przekraczająca ludzkie zdolności do jej przetwarzania. Możliwości te gwałtownie zmniejszają się wraz z czasem, jakim człowiek dysponuje. Przetwarzanie informacji generalnie odnosi się do wszystkich procesów zaangażowanych w przyjmowanie, przechowywanie i transfer informacji, obejmujących przetwarzanie technologiczne informacji (tzw. przetwarzanie danych) oraz przetwarzanie informacji przez czynnik ludzki. $\mathrm{Z}$ punktu widzenia menedżera szczególnie istotny jest ten drugi aspekt, odnoszący się do kognitywnego procesu przetwarzania informacji.

Powszechnie uważa się, że stan przeciążenia informacyjnego nasilił się wraz $\mathrm{z}$ rewolucją $\mathrm{w}$ technologiach informatycznych [Bawden 2001]. Postęp technologiczny w zakresie narzędzi informacyjno-komunikacyjnych działa bowiem jak broń obusieczna: z jednej strony wpływa na szybszy i tańszy przepływ oraz dostęp do informacji, z drugiej jednak przyczynia się do wzrostu jej ilości i różnorodności, prowadzącej do utrudnienia przetwarzania informacji i dysonansu poznawczego odbiorców [Bawden i in. 1999]. Łatwa i szybka komunikacja internetowa (w tym brak pośrednictwa w przekazywanych informacjach), media społeczne oraz wzrastająca proliferacja różnego rodzaju baz danych przyczyniają się do „syndromu zmęczenia informacyjnego" (information fatigue syndrome) [Edmunds, Morris 2000]. Sytuacja ta jest szczególnie problematyczna w przypadku konieczności szybkiego reagowania na dynamiczne zmiany i podejmowania szybkich decyzji. Menedżerowie funkcjonując w społeczeństwie informacyjnym, są poddawani ogromnym ilościom informacji, w tym także niezamawianej i nieposzukiwanej przez nich. Oczywistym problemem staje się wydobycie z masy informacji tych, które są rzeczywiście istotne dla podejmowanych decyzji. Wyzwaniem nie staje się poszukiwanie informacji, lecz raczej jej umiejętne filtrowanie.

\section{Heurystyczne podejmowanie decyzji i mechanizmy adaptacyjne}

Zgodnie z osiągnięciami psychologii poznawczej przeciążenie informacyjne skłania jednostkę do przyjęcia określonych mechanizmów adaptacji [Gigerenzer, Gaissmaier 2011]. Jedną z podstawowych metod adaptacyjnych wskazywanych w ostatnich latach w psychologii poznawczej jest heurystyczne podejście do podejmowania decyzji strategicznych, ignorujące część informacji. Ogólnie rzecz biorąc, heurystykę można rozumieć jako strategie decyzyjne wynikające $\mathrm{z}$ doświadczeń z podobnymi problemami, z wykorzystaniem łatwo dostępnych, choć luźno stosowanych informacji do rozwiązywania problemów, uczenia się lub odkrywania [Mousavi, Gigerenzer 2014]. To podejście zaprzecza szkole człowieka ekonomicznego (homo oeconomicus), która utrzymuje, że decydenci rozważają i oceniają wszystkie dostępne informacje w celu dokonania osądu. W jego miejsce postuluje się istnienie „człowieka heurystycznego" (homo heuristicus) [Gigerenzer, Brighton 2009]. W przeciwieństwie do racjonalnych ekonomicznych decyzji heurystyki nie dążą do optymalizacji, rozumianej jako wybór najlepszego rozwiązania, lecz do wyboru satysfakcjonują- 
cego, czyli wystarczająco dobrego [Gigerenzer, Brighton 2009]. Heurystyczne podejście do podejmowania decyzji ma szczególną użyteczność w sytuacjach, kiedy należy działać elastycznie i niezbędne jest podejmowanie szybkich decyzji.

Mechanizmy adaptacyjne generalnie opóźniają moment, w którym osiągnięte zostaje przeciążenie informacyjne. Pierwszym mechanizmem jest selektywne przyjmowanie informacji pomagające zredukować kognitywne przeciążenie. Proces ten jest traktowany jako mechanizm psychologicznego filtru, który zabezpiecza jednostki od przymusu otrzymywania i przetwarzania wszystkich informacji, z którymi są konfrontowane. Przyjmują aktywnie tylko te informacje, które są związane z ich indywidualnymi potrzebami lub wypełnieniami przez nich zadaniami, świadomie ignorując resztę informacji. Decydenci dążą do ograniczenia ilości informacji do przetworzenia także w celu uniknięcia dysonansu kognitywnego. Oznacza on rozbieżność w przetwarzaniu informacji, kiedy różne postrzegane elementy nie pasują do całości. Im większa ilość informacji do przetworzenia, tym większe prawdopodobieństwo pojawienia się dysonansu poznawczego. $Z$ dysonansem poznawczym wiąże się zachowanie decydenta polegające na poszukiwaniu informacji redukujących dysonans, a unikaniu tych, które mogłyby go zwiększyć. Informacja, która nie zgadza się z czyjąś wizją lub osądem, tworzy dyskomfort. $Z$ drugiej strony informacja potwierdzająca własne wyobrażenie jest przyjmowana ze specjalną uwagą. Do opóźnienia wystąpienia przeciążenia informacyjnego może także przyczynić się stosowanie heurystycznych osądów będących uproszczonymi strategiami rozwiązywania problemów.

\section{Heurystyka jako strategia}

Już w początkach rozwoju behawioralnego nurtu ekonomii i zarządzania Herbert Simon uznał heurystykę za strategię, która kieruje wyszukiwaniem informacji i modyfikacją problemów w celu ich rozwiązania. Użył on terminu ,zadowalanie” (satisficing), zarówno jako ogólnego terminu dla wszystkiego, co nie jest optymalizowane, jak i dla konkretnej heurystyki, polegającej na następującej regule: aby wybrać dobrą alternatywę z serii opcji napotkanych sekwencyjnie, osoba wyznacza poziom aspiracji, wybiera pierwszą, która spełnia aspiracje, a następnie przerywa wyszukiwanie [Gigerenzer, Brighton 2009]. Według Simona ludzie polegają na heurystyce nie tylko dlatego, że ich ograniczenia poznawcze uniemożliwiają jej optymalizację, lecz także ze względu na wymagania środowiska zadaniowego.

Heurystyki są zatem zbliżone do strategii, które ludzie - świadomie lub nie stosują w celu uproszczenia realizacji zadań wymagających oceny, które w innym przypadku byłyby zbyt trudne do rozwiązania. Nieświadome stosowanie heurystyk często jest nazywane intuicją i oznacza sytuacje, kiedy decydenci wyczuwają, co robić, nie będąc w stanie wyjaśnić, dlaczego [Mousavi, Gigerenzer 2014]. W rzeczywistych kontekstach ludzie nie inwestują zbyt wiele czasu i energii, aby planować i przeprowadzać poszukiwania informacji systematycznie. Zamiast tego często zachowują się „,irracjonalnie”, stosując heurystyczne skróty. Mimo że heurystyki mogą 
nie gwarantować optymalnego rozwiązania, mogą ułatwić wyszukiwanie informacji. Heurystyka może być pomocna w sytuacji, gdy istnieje potrzeba szybkiego i skutecznego znalezienia informacji za pomocą prostych metod, które działały w podobnych sytuacjach w przeszłości.

Wykorzystanie heurystyki jako pomoc w podejmowaniu decyzji organizacyjnych stało się w ostatnich kilku latach ważną częścią dyskusji w literaturze dotyczącej strategii [Bingham, Eisenhardt 2014; Leatherbee, Sol 2016; Vuori, Vuori 2014]. Uważa się bowiem, że heurystyki reprezentują potencjał „,racjonalności” przewyższający bardziej tradycyjne podejścia oparte na zasobach i informacjach [Bingham, Eisenhardt 2011], zwłaszcza gdy środowisko otaczające organizację jest dynamiczne i trudne do przewidzenia [Eisenhardt $i$ in. 2010]. Wydaje się, iż szczegółowe procedury podejmowania decyzji i procedury mają zastosowanie do decyzji strategicznych głównie w środowiskach umiarkowanie dynamicznych, podczas gdy w środowiskach wysoce dynamicznych firmy muszą ,polegać na szybko stworzonej nowej wiedzy i iteracyjnym działaniu, aby uzyskać adaptacyjne, ale nieprzewidywalne wyniki" [Bingham i in. 2007, s. 1106].

Podejście heurystyczne w zakresie podejmowania decyzji strategicznych jest zbieżne z koncepcją ,prostych regul”, wskazywaną jako jedno z podejść w zarządzaniu strategicznym, obok pozycyjnego i zasobowego, zgodnie z którym firmy w warunkach niepewności uczą się tzw. prostych reguł, zdobywając doświadczenie procesowe podczas tworzenia i realizowania określonych strategii [Bingham, Eisenhardt 2011, 2014; Bingham, Haleblian 2012; Maitland, Sammartino 2015]. Twierdzi się, że ich szybkie i oszczędne zastosowanie sprawia, że proste reguły są efektywnymi procesami decyzyjnymi, ponieważ umożliwiają spontaniczną adaptację do nowych okoliczności i wykorzystywanie nadarzających się okazji. Z tego względu przyświecającą logiką podejścia prostych reguł jest logika szans. Trzon tych prostych zasad składa się z heurystyk rozumianych jako skróty poznawcze, które są używane, gdy informacje, czas i zdolność przetwarzania są ograniczone [Bingham, Eisenhardt 2011]. Zasady te odnoszą się zwykle do kilku wybranych najważniejszych procesów w firmie [Eisenhardt, Sull 2001].

Opierając się na podejściu „racjonalno-heurystycznym”, wykorzystanie heurystyki do poprawy wyników firmy jest ważnym tematem dyskusji w literaturze dotyczącej strategii [Bingham, Eisenhardt 2014; Eisenhardt, Bingham 2017; Maitland, Sammartino 2015; Vuori, Vuori 2014], szczególnie w odniesieniu do rynków o wysokim poziomie nieprzewidywalności. Badania dowodzą, że menedżerowie celowo opracowują unikatowe i specyficzne proste reguły, aby kierować strategicznymi procesami i decyzjami. Eisenhardt i Sull odkryli, że to podejście jest pozytywnie związane z wydajnością firmy [2001]. Zapewnia bowiem firmie możliwość utrzymania przewagi konkurencyjnej w dynamicznych środowiskach. Ponieważ rynki o dużej dynamice charakteryzują się obfitymi przepływami nieprzewidywalnych, szybkich i niejednoznacznych możliwości, wyzwaniem jest odkrycie najlepszych możliwości wśród ich „stogu siana” [Davis i in. 2007]. 
Do tej pory modele obliczeniowe pokazały, że na nieprzewidywalnych rynkach mniej reguł pomaga firmom osiągnąć trwałą pozycję konkurencyjną lub „pozostać na krawędzi chaosu" poprzez ustawienie struktury wystarczającej do osiągnięcia optymalnego poziomu koordynacji, elastyczności i improwizacji [Davis i in. 2009]. Co więcej, ostatnie prace pokazały, że organizacje faktycznie rozwijają lub „uczą się” prostych, idiosynkratycznych reguł, gdy firma zdobywa doświadczenia metodą prób i błędów [Bingham, Haleblian 2012]. Oznacza to, że przeszłe wydarzenia, które wydają się często opóźniać obecne wyniki, są wyuczone i wykorzystywane jako predykatory dla wyników w przyszłości. Co więcej, bardziej wyrafinowani menedżerowie opracowują i doskonalą portfel prostych zasad, które kierują ich wiążącymi decyzjami [Bingham, Eisenhardt 2011]. Wsparcie empiryczne dla tego obszaru badań jest jednak niewielkie i ograniczone do kilku studiów przypadku.

Pojawia się ważne wyzwanie, aby połączyć teorię racjonalno-heurystyczną z odkrywaniem i chwytaniem możliwości strategicznych na dynamicznych rynkach, gdy możliwości są obfite i wysoce niepewne.

\section{Luka badawcza w zakresie strategicznego wykorzystania podejścia heurystycznego}

Podejście racjonalnych heurystyk jest względnie nowe, dlatego efektywność decyzji menedżerskich i organizacyjnych podjęta na podstawie prostych reguł nie jest oczywista. Jako antecedencja wyników firmy zostało poparte jedynie kilkoma badaniami empirycznymi. Teoria ta nie była przedmiotem testowania w zbyt wielu warunkach. Zdaniem Eisenhardt i współautorów, strategia prostych reguł, alternatywna wobec podejścia zasobowego i pozycyjnego, nie jest podejściem uniwersalnym. Istotne jest zatem poznanie uwarunkowań zewnętrznych i wewnętrznych efektywności tej logiki strategicznej. Badaniami powinny zostać przy tym objęte zarówno mechanizmy adaptacyjne na poziomie indywidualnym menedżerów, jak i na poziomie organizacyjnym, będące reakcją na przeładowanie informacyjne w procesie dokonywania wyborów strategicznych.

Generalnie wyniki badań na temat efektywności decyzji heurystycznych są sprzeczne i w kontekście biznesowym niezwykle rzadkie. $Z$ jednej strony część badań [Kahneman, Tversky 1972, 1973] wskazuje w warunkach eksperymentalnych, że heurystyka kieruje indywidualnym zachowaniem, prowadząc do gorszych decyzji w porównaniu z decyzjami opartymi na statystycznym (optymalizacyjnym) rozumowaniu. Z drugiej strony Gigerenzer i in. [Gigerenzer, Brighton 2009; Gigerenzer, Gaissmaier 2011] argumentują, że heurystyka prowadzi do lepszych decyzji w wysoce dynamicznych układach. Podawanym przykładem są gry sportowe. Wyższość prostych reguł w podejmowaniu decyzji strategicznych często uzasadniano, odwołując się do badań wskazanego wyżej Gigerenzera dotyczących indywidualnych decyzji jednostek. Powstaje zatem istotne pytanie co do możliwości przenoszenia doświadczeń badawczych z poziomu jednostki indywidualnej na poziom organizacyjny [Vuori, 
Vuori 2014]. Niewiele bowiem wiadomo na temat tego, jak heurystyka faktycznie funkcjonuje w organizacjach. Istnieje ważna luka badawcza polegająca na braku odpowiedzi na pytanie: w jaki sposób heurystyka działa na poziomie organizacyjnym i jak wpływa na strategiczne wybory?

\section{Zakończenie i wnioski}

Mimo że założenie behawioralne dotyczące ograniczonej racjonalności menedżerów wydaje się obecnie powszechnie akceptowane, to dominujące teorie zarządzania strategicznego - podejście pozycyjne i zasobowe, silnie związane z ekonomią neoklasyczną - milcząco zakładają, że nawet jeśli racjonalność decydentów miałaby być ograniczona, to nadal dążeniem decydenta powinien być optymalny wybór strategiczny. Obydwa podejścia uznają optymalizację za najlepszy sposób podejmowania decyzji strategicznej, a redundancję informacji postrzegają wyłącznie pozytywnie. Odmiennym podejściem w stosunku do pozycyjnego i zasobowego jest podejście prostych reguł, przyjmujące behawioralną perspektywę zarządzania strategicznego i koncentrujące się przede wszystkim na rzeczywistych zdolnościach poznawczych decydentów oraz sposobów podejmowania decyzji strategicznych.

Analiza literatury wskazuje, że wciąż nieodkryte są mechanizmy tworzenia się heurystyk będących reakcją na nadmiar informacji, zwłaszcza na poziomie organizacyjnym. Proces ich tworzenia, w związku z tym, że odwołuje się nie tylko do indywidualnych doświadczeń strategicznych, lecz także do organizacyjnych, można uznać za proces strategicznego uczenia się organizacyjnego. Znacznym problemem wydaje się treść prostych reguł, które powinny gwarantować efektywne decyzje strategiczne w określonych warunkach. Badania tego typu wypełniłyby istotną lukę badawczą, jaką jest zrozumienie mikrofundamentów organizacyjnej elastyczności [Eisenhardt i in. 2016] w dynamicznym otoczeniu oraz w warunkach przeciążenia informacyjnego. Część deskryptywna takich badań powinna stanowić eksplorację wykorzystywanych narzędzi adaptacyjnych, w tym selekcję i strukturę stosowanych heurystyk. Badania preskryptywne z kolei powinny dotyczyć uwarunkowań efektywności heurystyk. Wyniki takich badań powinny przyczynić się do lepszego projektowania heurystyk z uwzględnieniem określonych cech otoczenia, co w rezultacie powinno wpłynąć na poprawę profesjonalizmu decyzji podejmowanych w rzeczywistym świecie.

\section{Literatura}

Arnott R., Greenwald B., Stiglitz J.E., 1994, Information and economic efficiency, Information Economics and Policy, vol. 6, no 1, s. 77-82.

Bawden D., 2001, Information Overload, Library i information briefings, vol. 92, s. 1-15.

Bawden D., Holtham C., Courtney N., 1999, Perspectives on information overload, Aslib Proceedings, vol. 51, no 8, s. 249-255. 
Bingham C.B., Eisenhardt K.M., Furr N.R., 2007, What makes a process a capability? Heuristics, strategy, and effective capture of opportunities, Strategic Entrepreneurship Journal, vol. 1, s. 27-47.

Bingham C.B., Eisenhardt K.M., 2011, Rational heuristics: The „simple rules” that strategists learn from process experience, Strategic Management Journal, vol. 32, no 13, s. 1437-1464.

Bingham C.B., Eisenhardt K.M., 2014, Response to Vuori and Vuori's commentary on , heuristics in the strategy context", Strategic Management Journal, vol. 35, s. 1698-1702.

Bingham C.B., Haleblian J.J., 2012, How firms learn heuristics: Uncovering missing components of organizational learning, Strategic Entrepreneurship Journal, vol. 6, no 2, s. 152-177.

Dean J.W., Sharfman M.P., 1993, Procedural rationality in the strategic decision-making process, Journal of Management Studies, vol. 30, no 4, s. 582-610.

Edmunds A., Morris A., 2000, The problem of information overload in business organisations: a review of the literature, International Journal of Information Management, vol. 20, no 1, s. 18-28.

Eisenhardt K.M., Bingham C.B., 2017, Superior Strategy in Entrepreneurial Settings: Thinking, Doing, and the Logic of Opportunity, Strategy Science, vol. 2, no 4, s. 246-257.

Eisenhardt K.M., Furr N.R., Bingham C.B., 2010, CROSSROADS-Microfoundations of Performance: Balancing Efficiency and Flexibility in Dynamic Environments, Organization Science, vol. 21, no 6, s. 1263-1273.

Eisenhardt K.M., Furr N.R., Bingham C.B., 2016, Flexibility in Dynamic Environments, Organization Science, vol. 21, no 6, s. 1263-1273.

Eisenhardt K.M., Sull D., 2001, Simple rules: Strategy as simple rules, Harvard Business Review, January, s. 107-116.

Gigerenzer G., Brighton H., 2009, Homo Heuristicus: Why Biased Minds Make Better Inferences, Topics in Cognitive Science, vol. 1, no 1, s. 107-143.

Gigerenzer G., Gaissmaier W., 2011, Heuristic Decision Making, Annual Review of Psychology, vol. 62, s. 451-482.

Kahneman D., Tversky A., 1972, Subjective probability: A judgment of representativeness, Cognitive Psychology, vol. 3, no 3, s. 430-454.

Kahneman D., Tversky A., 1973, On the psychology of prediction, Psychological Review, vol. 80, no 4, s. $237-251$.

Klausegger C., Sinkovics R.R., "Joy” Zou H., 2007, Information overload: a cross-national investigation of influence factors and effects, Marketing Intelligence i Planning, vol. 25, no 7, s. 691-718.

Leatherbee M., Sol P., 2016, Predicting Entrepreneurial Performance: Simple Rules versus Expert Judgment, Strategic Management Society Conference - Strategy Challenges in the 21st Century: Innovation, Entrepreneurship and Coopetition, June, s. 1-7.

Maitland E., Sammartino A., 2015, Decision making and uncertainty: The role of heuristics and experience in assessing a politically hazardous environment, Strategic Management Journal, vol. 36, no 10 , s. $1554-1578$.

Mintzberg H., Raisinghani D., Theoret A., 1976, The Structure of ,, Unstructured” Decision Processes, Administrative Science Quarterly, vol. 21, s. 246-275.

Mousavi S., Gigerenzer G., 2014, Risk, uncertainty, and heuristics, Journal of Business Research, vol. 67 , no 8 , s. 1671-1678.

Vuori N., Vuori T., 2014, Comment on , heuristics in the strategy context” by Bingham and Eisenhardt (2011), Strategic Management Journal, vol. 35, s. 1689-1697. 